\title{
APPROACHES TO AGRICULTURAL ENTERPRISES POSITIONING
}

\author{
Julia Subotina', Alexander Sergienko²
}

\begin{abstract}
With the development of market economic relations and the intensification of competition in Ukraine, the problem of adequate positioning of enterprises among competitors, as well as in the consumers' minds becomes relevant. The author summarizes scientific approaches of foreign and domestic scientists to the interpretation of the concept of "positioning", which are reflected in the following: F. Kotler (positioning as a way of identifying goods), J. Trout, E. Reiss (as a certain position of the enterprise among competing goods), Belyaeva N.S. (as an element of the enterprise strategic management system). Three basic components to understanding the essence of positioning are generalized and allocated: positioning as a concept that defines the ideological aspect in its definition (ideas and views), which are the basis of the enterprise product proposal; positioning as a strategy that involves the development of a competitive position of the enterprise product and the relevant marketing complex; positioning as a set of actions that characterizes a set of measures, specific ways to convey the position to the target segment in the implementation of marketing programs; so it is a set of tools to help forming a brand image that should strongly differ from competitors. Due to the fact that the agricultural component is important to the Ukrainian economy development, it is necessary to ensure the effective positioning of agricultural enterprises in foreign markets, which is the source of their sustainable competitive advantage. The opinions of Ukrainian scientists on the agricultural enterprises products positioning were summarized: Kozak L.V., who proposes strategies for the agricultural enterprises development; Kosharna P.S., who offers strategic tools for the agricultural enterprises; Artyukhova K.V. and Bondarenko V.V., who substantiate the necessary market position of agricultural enterprises. Approaches and factors for positioning of agricultural products that should be taken into account in the foreign economic activity of enterprises such as planning, staff, practice, partners that can strengthen opportunities, positioning, protection are analyzed. Peculiarities of agricultural enterprises products positioning were determined: production seasonality, high level of natural and climatic conditions dependence, role and value of products, variety of management organizational forms, time discrepancy in finished products growing and manufacturing, level of state participation in agro-industrial complex development. The author has formed a structural and logistical scheme of agricultural enterprises product positioning, which has the following main elements: purpose, means, conditions of activity, support (including the development of enterprise products positioning strategy) and marketing tools. The main marketing tools that must be used in positioning the products of agricultural enterprises include: the type of product, its quality, functional properties, type of packaging, guarantees; price formation conditions; logistics sales channels used in the delivery of products to the customer; products promotion; qualification of the personnel carrying out marketing support of agricultural enterprises production.
\end{abstract}

Key words: positioning, positioning of agricultural products, marketing strategy, positioning factors, positions of enterprises.

JEL Classification: Q13, Q16, P13

\section{Introduction}

One of the most effective areas in the activities of any company is the positioning of its product on the market. Positioning is an activity to ensure the product's competitive position in the market and the development of a detailed marketing mix. Many companies, starting their business and using marketing for the first time, successfully apply this direction. It is no secret that the correct and competent positioning of the product in relation to competing products allows

\footnotetext{
Corresponding author:

${ }^{1}$ Cherkasy State Technological University, Ukraine.

E-mail: jul.subotina@gmail.com

ORCID: https://orcid.org/0000-0003-3717-3231

${ }^{2}$ Cherkasy State Technological University, Ukraine.

E-mail: sergienko07@ukr.net

ORCID: https://orcid.org/0000-0001-5061-4287
} 
it to provide current positions that bring significant profits. An important step in choosing the direction of market orientation of the organization is to determine the position of the product in individual market segments. Product positioning primarily refers to the definition of a certain group of consumers, target market segments, relative to the most important properties of the product. It characterizes the place that a particular product occupies in the minds of consumers in relation to the product of competitors. The product must be perceived by a certain group of target consumers as a clear image, which distinguishes it from the products of competitors. Of course, you must also take into account the fact that the position of the product is influenced by the reputation and image of the company as a whole. The positioning of the product, therefore, is that, based on consumer assessments in the market of a particular product, to choose such product parameters and elements of the marketing mix, which in terms of target consumers will provide the product with competitive advantages.

The issue of positioning of Ukrainian agricultural enterprises engaged in the sale of agricultural products is becoming increasingly important. It is important not only to expand the influence in the domestic market, but also to penetrate and conquer foreign markets. Effective positioning of the company shapes its image and success in the markets. Positioning, as a component of marketing, determines the need for detailed theoretical and practical research, given the lack of sufficient thorough work on this issue by domestic scientists and, accordingly, the lack of foundation for the practical implementation of this element of marketing policy.

\section{Review of literature sources in accordance with the research issues}

A large number of researchers are currently dealing with the positioning of enterprises in the markets, as the marketing program is an integral part of the company's sales policy. At the same time, many works of scientists are devoted to the positioning of agricultural products. In particular, one of the leading scientists engaged in marketing positioning of the enterprise is Kozak L.V. (Kozak, 2014), who in his works considers theoretical and methodological approaches to the formation of strategic vision and goals of positioning products of agricultural enterprises, the formation of strategies for agricultural enterprises positioning products and world markets. The research of Kosharna P.S. (Kosharna, 2015) on the formation of strategic tools for positioning the products of agricultural enterprises, Artyukhova K. V. and Bondarenko V.V. (Artyukhova, Bondarenko 2015) - on the formation of the market position of agricultural enterprises, Petryk O. O. (Petryk, 2016) - on the formation of an enterprise competitive positioning strategy in foreign markets, Belyaeva N. S. (Belyaeva, 2016) - on strategic positioning as an element of strategic management of the enterprise, F. Kotler (Kotler, 2002) - positioning is a set of measures by which in the minds of target customers the product in relation to competing products occupies its own, different from others and profitable for the company, the way in which consumers identify a product by its most important characteristics, J. Trout and E. Rice (Trout, Rice, 2004) - the creation of a product certain position among competing products, a kind of niche that would be reflected in the hierarchy o $\mathrm{f}$ values created in the minds of potential buyers. In these works, a study of the positioning basics of Ukrainian enterprises in foreign markets is initiated mainly from a theoretical point of view, identified features of agricultural enterprises positioning in general and individual sectors of agriculture in particular. To date, the issue of positioning the products of Ukrainian agricultural enterprises in international markets can be considered fully open.

\section{Theoretical basis for the formation of enterprise positioning}

The generalization of the main approaches to understanding the category of "positioning" made it possible to identify the following features. First, positioning is more a long-term strategy than a shortterm tactic. Properly selected positions are stable, protected and adapted to the conditions and future development. They are able to evolve and change at the stages of the life cycle of a product, brand, firm. Second, positioning occurs in the minds of consumers, and therefore, it is what the consumer thinks about the company, product or service. Third, positioning is based on the benefits that the consumer receives from the purchase of goods or a partner from cooperation with the company. Fourth, because positioning is based on benefit, and because different customers often look for different benefits from buying, using, in fact, similar products and services, the position of an individual product in the perception of one buyer may differ from the position of this the product itself from another buyer. Finally, positioning is a relative concept. Products and brands occupy positions relative to competing products and brands.

The founders of the theory of positioning defined it as "the creation of a certain position for the product among competing products, a kind of niche that would be reflected in the hierarchy of values created in the minds of potential buyers, the development of such an image of the product. competing products (Trout, Rice, 2004). The basic principle of positioning, in their opinion, is not to create something new and different from others, but to manipulate thoughts that already lives in the minds of consumers, to use existing connections. 
Positioning was a fashionable expression in advertising and marketing circles in the 1970s, and the word "positioning" characterized the development of advertising. That is, in essence, positioning was originally used as a tool to improve the effectiveness of advertising or the process of identifying the competitive advantages of the company's products and their subsequent use in promotions and other aspects of promotion.

After 15 years of the predominance of the positioning theory of Ella Rice and Jack Trout, a lot of work has appeared on the concept of "positioning". However, despite numerous publications (in the United States alone over the last 30 years, more than a hundred major papers have been published on positioning), there is still no consensus among marketing practitioners and theorists on what positioning is. This is confirmed by the description of the current state of understanding the term, given by P. Bainsfeir: "Positioning - a word that is used by all but few understand" (Bainsfeir, 1990).

Considering the concepts of "positioning" presented in the modern theory of interpretation, the author identified three of its basic components: positioning as a set of actions; positioning as a concept; positioning as a strategy. The content of these components is summarized in table 1 .

Positioning as a concept is considered in the works of E. Rice and D. Trout - the founders of the concept, who said that it is important to build positioning on a strong concept, it will distinguish the company from a number of competitors.

This approach includes the ideas of David Krevens, who defines positioning as the formulation of the essence of the company's offer, which indicates the ability of the organization to meet the needs and preferences of consumers (Krevens, 2003). The concept of positioning should be based on the reasons why customers prefer to do business with it, rather than its competitors, and broadcast these reasons to the target audience.

The essence of positioning according to this approach is to formulate the essence of the company's proposal (concept) taking into account the needs of the target segment, the expectations of other groups and the understanding of the benefits for the company itself.

Positioning as a strategy. According to this approach, positioning is defined as the process of developing a competitive position for a product and the relevant marketing complex.

F. Kotler in his works on marketing defines positioning as a process by which a product is distinguished by consumers by its main characteristics, ie the place that this product, according to consumers, occupies compared to similar products offered by competitors (Kotler, 2002).

Consumers are overwhelmed with information about goods and services, they cannot evaluate every offer every time they make a purchase decision. To simplify the procedure for making a purchase decision, consumers divide goods and services into different categories, ie they mentally "position" the products offered to them.

David Aaker defines positioning as the process of creating image and value in consumers mind from the target audience so that they understand why there is a company or brand compared to competitors (Aaker, 1995).

Hooley Graham follows a similar approach, believing that positioning is a thoughtful, proactive and repetitive process of determining, measuring, modifying and monitoring consumer perception of the object that is exposed to marketing influence (Graham, 2005).

Thus, based on these formulations, as well as on the general economic and managerial interpretation of the term "strategy" (plan to achieve long-term goals), we can conclude that positioning is characterized as a long-term process (strategy) aimed at achieving and maintaining the desired competitive position. market.

T. Ambler describes positioning as a set of actions. This approach characterizes positioning as a set of measures, specific ways to convey the position to the target segment during the implementation of marketing programs, as follows: it is a set of tools to help form a brand image, and this image should be as different as possible from competitors' brands. use both real and imaginary characteristics of the product or service (Ambler, 2006).

S. Garkavenko defines positioning as marketing efforts of the corporation to develop and implement in the minds of target consumers a special image of the company, product, service, which differs from what competitors offer (Garkavenko, 2002).

Thus, the essence of this approach is that positioning is seen as a set of elements of communication policy that are perceived by the consumer. If each proposal

Table 1

Components of the "positioning"

\begin{tabular}{|c|l|}
\hline Components & \multicolumn{1}{c|}{ Content } \\
\hline Conceptual (positioning as a concept) & $\begin{array}{l}\text { Reflects the ideological aspect in the definition of positioning as a system of ideas, views (formulation } \\
\text { of the proposal essence) }\end{array}$ \\
\hline Strategic (positioning as a strategy) & Considers positioning as a strategy (methodology for competitive position developing) \\
\hline Functional (positioning as a set of actions) & Defines positioning as a set of actions or a set of measures (a set of marketing tools and actions) \\
\hline
\end{tabular}

Source: compiled by (Trout, Rice, 2004; Bainsfeir, 1990; Krevens, 2003; Kotler, 2002; Aaker, 1995; Graham, 2005; Ambler, 2006) 
occupies a certain position in the minds of the client, then positioning is a policy of influencing the perception of this proposal.

\section{Marketing tools for product positioning of agricultural enterprises}

In modern conditions of economic instability, the problem of using positioning in the management of agricultural enterprises becomes especially important. Modern entrepreneurial activity is characterized by a high degree of competition in the market, which requires agricultural enterprises to pay more attention to ensuring their competitiveness. In addition, the Ukrainian agro-industrial complex, being one of the main sectors of the national economy, due to the specifics of its economic and production activities, depends on many other sectors of the economy. This problem in the agro-industrial complex of Ukraine negatively affects the pace of development of this complex. The solution of the above problems depends on how correctly and economically justified agricultural enterprises will develop or select their competitive product positioning strategies. They can increase the efficiency of economic and marketing activities of agricultural enterprises, as well as ensure high competitiveness in the domestic and foreign markets.

To achieve this goal, the company must develop a set of marketing tools, which should ensure effective positioning of the company and its products in the target market. It is necessary to provide a systematic approach to the formation of strategies for positioning individual elements of the marketing complex: to agree on their goals and general direction. Effective positioning and development of an appropriate marketing complex for the target market is a source of sustainable competitive advantage of the enterprise in this market.

To achieve this goal, the company must develop a set of marketing tools, which should ensure effective positioning of the company and its products in the target market. It is necessary to provide a systematic approach to the formation of strategies for positioning individual elements of the marketing complex: to agree on their goals and general direction. Effective positioning and development of an appropriate marketing complex for the target market is a source of sustainable competitive advantage of the enterprise in this market.

To position agricultural products, companies must emphasize the distinctive features of their product, or try to create an appropriate image through a marketing combination. As soon as the company takes a leading position, it becomes competitive. In the foreign market there are factors "6P", which should be taken into account during the foreign economic activity of the enterprise (Kharenko, Bobko, 2016):

1) planning - business, market, sales strategies, etc.;
2) staff-identifying the necessary skills for development and delivering the product;

3) practice - business practice within the culture of the target market;

4) partners who can strengthen opportunities;

5) positioning - how the company wants to be perceived by intermediaries and customers;

6) protection - assessment of potential risks in all aspects of the enterprise.

Therefore, we see that the company's positioning in terms of this approach is a significant factor in the competitiveness of the enterprise. Positioning is one of the most powerful marketing concepts. Initially, product-oriented positioning became increasingly popular, including the creation of product image and ranking among competitors' products. First of all, we are talking about "the place that the brand occupies in its target audience subconscious".

Product positioning is often used as a tool to enter foreign markets. There is no single interpretation of the enterprise "market position" concept or product in the foreign literature on product marketing management. If foreign authors widely use the category of the enterprise market position during the study of effective sales management, then for domestic researchers is more typical to use the conceptual apparatus of product positioning, as a result of market segmentation by commodity price or consumer criteria (Kozak, 2015).

The organization of agricultural enterprises product positioning is carried out taking into account the peculiarities of agriculture, namely: seasonality of production, high level of dependence on climatic conditions, role and importance of products, diversity of management organizational forms, time discrepancy in growing and manufacturing finished products, level of state participation in the complex development, etc. (Lohosha, 2018).

In the conditions of constant competition aggravation, there is a need for positioning of the enterprise production. Quite a clear and comprehensive definition of positioning offers Kozak L.V., as a direction of future product development in the market on the basis of initially formed consumer value, able to most effectively meet the needs of consumers. In addition, in accordance with the modern concept of multiattribution, the product acquires unique properties through a professional symbiosis of its functional and associative qualities that meet the needs of consumers (Kozak, 2015).

Figure 1 shows the structural and logical scheme of agricultural enterprises product positioning.

The products of agricultural enterprises should be considered not only in accordance with standard qualities (satisfaction of food needs), but also as services and ideas. It is important to offer ideas that promote care for the environment, care for safe and healthy food for customers. 


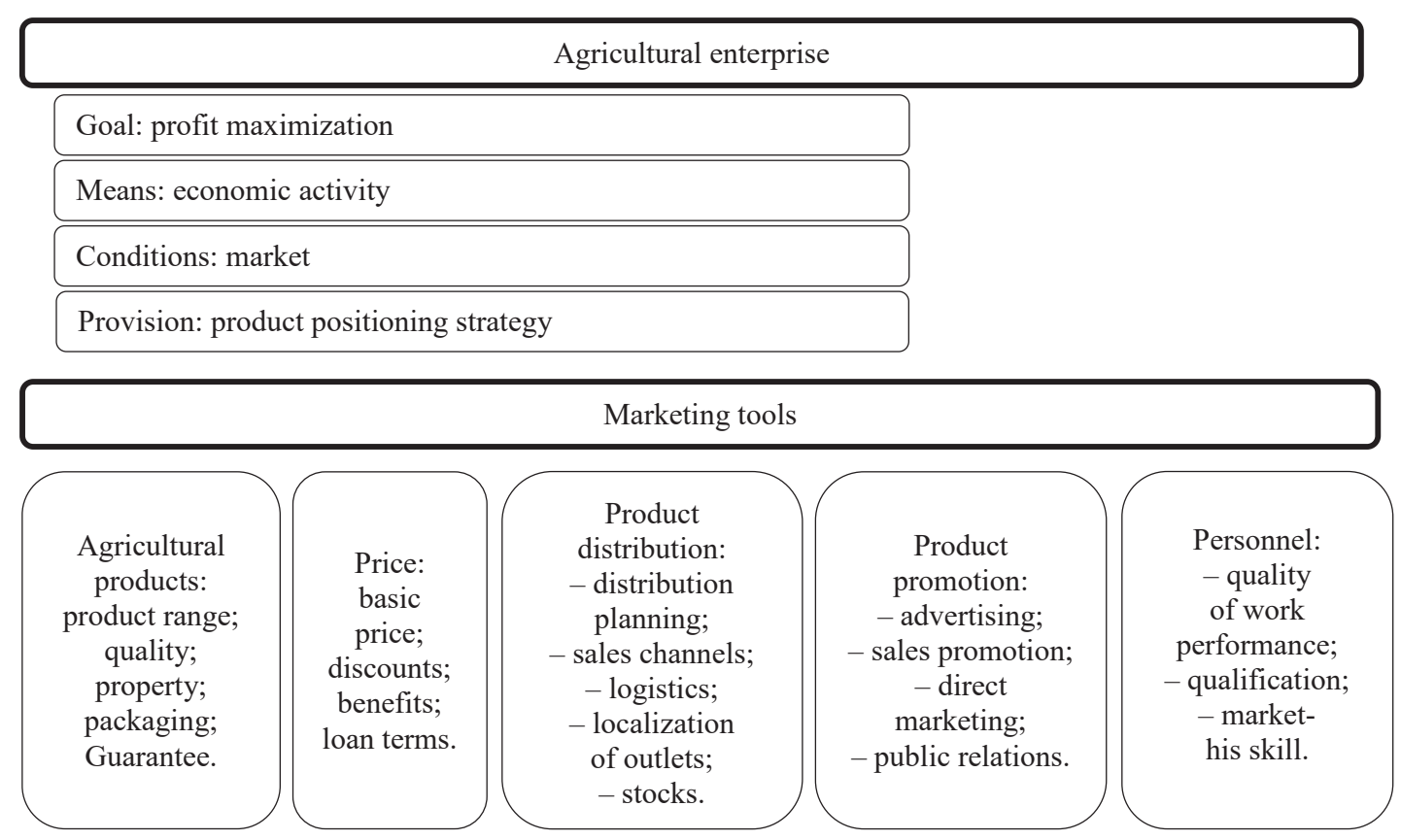

Figure 1. Structural and logical scheme of product positioning of agricultural enterprises

Source: built by the author according to the data (Dudar, 2017; Krevens, 2003)

\section{Conclusions}

Summing up, we note: positioning-is one of the most important marketing processes, which determines the adequate market position of the product or enterprise as a whole. Positioning is characterized by multifaceted actions and requires separate consideration; tactics indicate the relationship with the marketing mix, and in the latter the main role is given to promotion. Because positioning is based on consumer value, which in any approach includes a category of quality, the article examines the nature and relationship of these important marketing categories. There is a close link between positioning and internal marketing, which stems from the relationship between the above categories.

The main approaches to understanding the category of "product positioning" are considered and the characteristic features and components of the agricultural enterprises product positioning strategy are highlighted. While creating a marketing strategy for positioning the agricultural enterprises products they should coordinate their potential to meet the end users needs in terms of range, quality and price; take into account the maximum use of their own competitive merits and weaknesses of opponents.

Achieving the goal of increasing sales in today's market competition without proper product positioning sometimes becomes an impossible task. Actually, this is the product positioning on the market. In fact, product positioning in the market is a search for new ways to consolidate the image of your brand or product in the minds of buyers, creating and developing models to promote products to increase sales activity.

The mechanism of agricultural enterprises products effective positioning provides for the integrity, unity, orderliness of all steps. The prospect of further research is to determine the methodological tools for selecting and implementing positioning strategies, as well as assessing the positioning effectiveness and providing forecasts on the possible consequences of their implementation.

\section{References:}

Kozak, L. V. (2014). Theoretical and methodical approaches to the formation of strategic training and the goal of positioning the products of agricultural enterprises. Scientific notes of the National University "Ostrozka Academy", series "Economics", vol. 25, pp. 42-49. Available at: http://ecj.oa.edu.ua/articles/2014/n25/10.pdf

Kozak, L. V. (2015). Formuvannia strategii pozitsiuvannia produktsii agrarnykh pidpryiemstv na vitchyznyanomu ta svitovykh rynkakh [Formation of strategies for positioning the products of agricultural enterprises in the domestic and world markets]. Kyiv. (in Ukrainian)

Kosharna, P. S. (2015). Formuvannia stratehichnoho instrumentaria pozitsionuvannia pidpryiemstva [Formation of strategic tools for enterprise positioning]. Available at: http://www.hneu.edu.ua/web/public/moved/hneu/ NAUKA/Vchenna_rada/KosharnaP.S.-Disertaciya.pdf

Artyukhova, K. V., \& Bondarenko, V. V. Formation of the market position of agricultural enterprises. Available at: http://www.khntusg.com.ua/files/tez3.pdf 
Petryk, O. O. (2016). Formuvannia strategii konkurentnoho pozitsiyuvannia pidpryiemstva na zarubizhnomu rynku [Formation of the strategy of competitive positioning of the enterprise in the foreign market]. Kyiv. Available at: http://management.fmm.kpi.ua/wp-content/uploads/2016/02/avtoref_Petryr_2016.pdf

Belyaeva, N. S. (2016). Strategic positioning as an element of the system of strategic management of the enterprise. Scientific Bulletin of the International Humanities University, vol. 1, pp. 119-123. (in Ukrainian)

Trout, J., \& Rice, E. (2004). Positioning. The Battle for Recognition. Translated from English by S. Zhiltsova. $\mathrm{SPb}$ : Peter. (in Russian)

Bainsfair, P. (1990). Create your own context and find place in a public mind. Campaign, vol. 16, (November), p. 18. Krevens, D. V. (2003). Strategic marketing. Translated from English by A. R. Ganieva, A. G. Grishko, E. V. Kondukova. Moscow: Williams. (in Russian)

Kotler, F. (2002). Marketing. Hospitality. Tourism. Moscow: UNITI. (in Russian)

Aaker, David A. (1995) Strategic market management, Fourth ed. New York, NY: John Wiley \& Sons, Inc.

Hooley, G. (2005). Marketing strategy and competitive positioning. Translated from English. Balance Business Books. (in Russian)

Ambler, T. (2006). Practical marketing. Translated from English ; under total. ed. Yu.N. Kapturevsky. St-Petersburg: Peter. (in Russian)

Garkavenko, S. S. (2002). Marketing: textbook. Kyiv: Libra. (in Ukrainian)

Kharenko, A. O., \& Bobko, V. V. (2016). Osoblyvosti zbutovoi diialnosti silskohospodarskykh pidpryiemstv: rehionalni aspekty [Features of marketing activities of agricultural enterprises: regional aspects].Zbirnyk naukovykh prats Umanskoho natsionalnoho universytetu sadivnytstva, vol. 88(2), pp. 319-334. (in Ukrainian)

Kozak, L. V. (2015). Formuvannia stratehii pozytsiiuvannia produktsii ahrarnykh pidpryiemstv na vitchyznianomu ta svitovomu rynkakh [Formation of strategies for positioning agricultural products on domestic and world markets]: monohrafiia. Ostroh: Vydavnytstvo Natsionalnoho universytetu «Ostrozka akademiia». (in Ukrainian) Lohosha, R. V., \& Polova, O. L. (2018). Osoblyvosti formuvannia marketynhovykh stratehii silskohospodarskykh pidpryiemstv [Features of formation of agricultural enterprises' marketing strategies]. Mizhnarodnyi naukovyi zhurnal «Internauka», vol. 11(2), pp. 22-26. (in Ukrainian)

Dudar, T. H., \& Dudar, V. T. (2017). Marketynhovi instrumenty zabezpechennia pozytsionuvannia na rynku orhanichnoi produktsii [Marketing tools for positioning at organic produce market]. Naukovyi visnyk Uzhhorodskoho universytetu. Seriia: Ekonomika, vol. 1(2), pp. 71-76. (in Ukrainian) 